UDK: 314.116(497.6)"1996/2001"

doi:10.5937/gads1247203P

\title{
PROJEKCIJE RAZVOJA MLADE (ŠKOLSKE) POPULACIJE REPUBLIKE SRPSKE IZ DEMOGRAFSKE PERSPEKTIVE
}

\author{
Stevo Pašalić, Mitar Novaković, Momčilo Pelemiš \\ Univerzitet u Istočnom Sarajevu
}

\section{Sažetak}

Značaj ovog naučnoistraživačkog rada je u tome što sagledava postojeće stanje i daje viziju razvoja demografskih potencijala školske populacije u interakciji sa društveno-ekonomskim razvojem Republike Srpske. Opšta hipoteza (koja proizilazi iz cilja istraživanja) jeste da se istraživana pojava svrstava u jednu od ključnih komponenti sveukupnog razvoja Srpske i da je ona posljedica demografije, što zahtjeva novi pristup u projekciji razvoja navedene pojave. Očekivani rezultati u ovom istraživanju imaju posebnu vrijednost za društvenu zajednicu, kao što su razvoj školske populacije na svim nivoima i međuzavisnost sa društveno-ekonomskim razvojem Republike Srpske. U istraživanju o bilansima školske populacije na svim nivoima, prati se razvoj pojave od momenta raspolaganja bazom podataka, a istraživanja treba da daju određene preporuke o usklađivanju obrazovnih profila koji se školuju na visokoškolskim ustanovama sa potrebama tržišta rada u Republici Srpskoj.

Ključne riječi: populacija, kontigenti, obrazovni profili, ljudski resursi.

\section{Uvod}

Demografski kontigenti mlade populacije Republike Srpske predstavljaju najvažniji dio njenog obrazovnog sistema. Funkcionisanje tako kompleksnog sistema jako utiče na mnoge segmente društva, a posebno društveno-ekonomskog razvoja. Prostor Republike Srpske još uvijek karakteriše kasna faza demografske tranzicije, koja je uslovljena ekonomskim razvojem, slabom iskorišćenošću prirodnih resursa i dosta povoljnim saobraćajnogeografskim položajem, što je pokrenulo poremećaje biološkog kretanja, smanjenje stope prirodnog priraštaja i proces starenja stanovništva (Pašalić S. i sar., 2006).

Republika Srpska spada u niskonatalitetna područja (ispod 10\%). Bruto stopa fertiliteta je veoma niska, što je posljedica planiranja porodice, postratnih trauma, raseljavanja i procesa izbjeglištva, ali i veoma teške socijalno-ekonomske situacije, psiholoških i drugih faktora. Smanjeno rađanje je direktan uzrok opadanja populacije školskog uzrasta na svim nivoima.

Kretanje broja stanovnika Republike Srpske veoma je nezahvalno za naučne analize, jer na ovom prostoru od 1991. godine nije sproveden popis stanovništva.

Prema podacima za 1991. godinu, Republika Srpska je u okviru sadašnjih granica imala 1.623.842 stanovnika, što je 37\% ukupnog stanovništva tadašnje Bosne i Hercegovine. Prema procjenama Republičkog zavoda za statistiku Republike Srpske, broj stanovnika 2008. godine iznosio je $1.437 .477^{1}$ stanovnika.

Četiri godine rata ostavile su ozbiljne društveno-ekonomske, posebno demografske posljedice, koje će se manifestovati i u narednim decenijama društveno-ekonomskog i demografskog razvoja Republike Srpske. 
Međuzavisnost uticaja demografskih i prostornih faktora rezultirali su uspostavljanjem specifičnih prostorno-demografskih odnosa, koji po svojim karakteristikama Republici Srpskoj daju obilježja izrazito heterogenog prostora. Skoro dvije trećine ili $63,3 \%$ stanovništva Srpske koncentrisano je u zapadnom dijelu, od Distrikta Brčko do Novog Grada, dok ostalo stanovništvo pripada istočnom dijelu, južno od Rače na Savi do Trebinja i juga istočne Hercegovine. Urbane sredine, uglavnom, ostvaruju demografski rast, zahvaljujući mehaničkom prilivu stanovništva. Nasuprot tome, u ruralnim sredinama, u najvećem broju slučajeva, dolazi do slabijeg demografskog rasta, koji je uglavnom uslovljen emigracijom i poremećajima biološkog karaktera (Pašalić i sar., 2006).

Dinamika kretanja broja stanovnika Republike Srpske je različita i u pojedinim regionalnim cjelinama, opštinama i naseljima. Ravničarsko-brežuljkasti prostori sjevernog dijela imaju određeno povećanje, dok kraški prostori istočne Hercegovine i jugozapadni dijelovi Krajine i planinski prostori u istočnom dijelu Srpske imaju manji porast ili smanjenje broja stanovnika.

Prostor Republike Srpske još uvijek karakteriše kasna faza demografske tranzicije, koja je uslovljena ekonomskim razvojem, slabom iskorišćenošću prirodnih resursa i veoma povoljnim saobraćajno-geografskim položajem, što je pokrenulo poremećaje biološkog kretanja, smanjenje stope prirodnog priraštaja i proces starenja stanovništva. U periodu 1996-2008. godine opšta stopa nataliteta u Srpskoj je u konstantnom padu, dok opšta stopa mortaliteta ima tendenciju rasta, što je $u$ vezi sa povećanjem udjela najstarije populacije $u$ ukupnom stanovništvu.

Odnos rađanja i smrtnosti uslovio je stanje i promjene u prirodnom priraštaju u pojedinim opštinama Srpske. Podaci za 2008. godinu ukazuju da 58 opština ima negativnu stopu prirodnog priraštaja, dok samo četiri opštine imaju pozitivnu stopu. Dakle, izuzetno veliki broj opština zahvaćen je depopulacijom. Ovo je posebno izraženo u sjeverozapadnim $\mathrm{i}$ itočnim dijelovima Srpske.

Veoma važan faktor dosadašnjeg, ali i budućeg, demografskog razvoja Srpske predstavljaju migracije stanovništva, koje iako ispoljavaju trendove nešto slabijeg intenziteta, za posljedicu imaju negativan migracioni saldo. Demografske analize ukazuju da Srpska od završetka rata 1995. godine u $\mathrm{BiH}$, ima izrazito emigraciono obilježje, a posebno njen istočni i jugozapdani dio. Unutrašnje migracije se odvijaju ustaljenim pravcima iz nerazvijenih izolovanih i zapuštenih područja u privredno razvijenije sredine.

Strukture stanovništva Srpske ukazuju na značajnu heterogenost između gradskih centara i privredno razvijenih područja, koja imaju pravilniju strukturu, sa većim udjelom mladog stanovništva, u odnosu na brdsko-planinska područja, gdje se značajno smanjuje udio mladog stanovništva.

Smanjenje kontigenta mladog stanovništva odrazilo se i na konstantno opadanje školske populacije, od 1995. godine do 2009. godine.

\section{Materijal i metode}

Projekcija razvoja mlade (školske) populacije je složen problem, u čijem se istraživanju primjenjuje posebna metodologija, koja se razlikuje od uobičajenih sinteznih pristupa i istovremenim istraživanjima u vremenu i prostoru.

U istraživanju su korišćene naučne metode koje su međusobno komplementarne i koje istraživanje čine temeljnim i potpunim. U analizama ovakve problematike poželjno je kombinovanje više istraživačkih metoda (multi-method). To je situacija gdje se jedna metoda oslanja na drugu, u cilju efektivnog istraživačkog koncepta.

Metod klasifikacije je jedan od najjednostavnijih metoda gdje se nastoji određeni opšti pojam klasifikovati na posebne pojmove u okviru obima opšteg pojma. 
- Metod sistematskog pristupa iskazuje proces koji zahtijeva optimalne promjene, a kome se pristupa kao stohastičkom (vjerovatnosnom).

- Matematičko-statistički metod svodi se na najjednostavnije metode klasifikacije, gdje će posebno biti značajno korišćenje različitih metoda obrade statističkog materijala. Posebno će statistički materijali omogućiti otkrivanje uzajamnih veza ili uzroka zavisnosti među školskom populacijom.

- Metod analize i sinteze dovodi do naučnog opisivanja i saznanja, a njihovom kombinacijom sa metodom definicije i dokaza kompleksno se sagledava školska populacija na svim nivoima.

- U istraživanjima su se, po potrebi, koristile i novije naučne metode, kao što su WBS metod, Organization breakdown structure metod, Milestone metod i dr.

\section{Rezultati i diskusija}

Opšta stopa nataliteta najdirektnije utiče na brojnost školske populacije u Srpskoj. Baza podataka o rađanju stanovništva Srpske postoji od 1996. godine i na osnovu tih podataka mogu se pratiti njeni učenički kapaciteti. Posljednja generacija koja je upisana u osnovnu školu je generacija rođena 2003. godine.

Broj rođenih u Srpskoj bio je u uzlaznoj putanji sve do 2000. godine, dok je smanjenje rađanja evidentno od 2001. godine, što se bitnije odrazilo i na smanjeni broj upisanih učenika u osnovnu školu.

Tabela 1. Odnos broja rođenih i broja upisanih učenika u osnovnu školu u Republici Srpskoj Table 1. Ratio of the number of births and the number of pupils enrolled in primary school in Republic of Srpska

\begin{tabular}{|c|c|c|c|c|}
\hline $\begin{array}{c}\text { Godina } \\
\text { rođenja } \\
\text { (Year of } \\
\text { birth) }\end{array}$ & $\begin{array}{c}\text { Broj rođenih } \\
\text { (Number of } \\
\text { births) }\end{array}$ & $\begin{array}{c}\text { Godina upisa u } \\
\text { školu } \\
\text { (Year of school } \\
\text { enrollment) }\end{array}$ & $\begin{array}{c}\text { Broj upisanih } \\
\text { učenika } \\
\text { (Number of } \\
\text { enrolled pupils) }\end{array}$ & $\begin{array}{c}\text { Index } \\
(4 / 2)\end{array}$ \\
\hline 1995. & - & $2002 / 2003$ & 14.203 & - \\
\hline 1996. & 12.236 & $2003 / 2004^{2}$ & $\begin{array}{c}\text { upisani u II razred } \\
\text { (enrolled in } \\
\text { second grade) }\end{array}$ & - \\
\hline 1997. & 13.757 & $2003 / 2004^{3}$ & 11.088 & 80,60 \\
\hline 1998. & 13.527 & $2004 / 2005$ & 12.201 & 90,20 \\
\hline 1999. & 14.500 & $2005 / 2006$ & 11.638 & 80,26 \\
\hline 2000. & 14.191 & $2006 / 2007$ & 11.767 & 82,92 \\
\hline 2001. & 13.699 & $2007 / 2008$ & 11.575 & 84,50 \\
\hline 2002. & 12.366 & $2008 / 2009$ & 10.586 & 85,81 \\
\hline 2003. & 12.066 & $2009 / 2010$ & 10.800 & 84,34 \\
\hline 2004. & 11.920 & $2010 / 2011$ & 10.400 & 87,24 \\
\hline
\end{tabular}

Izvor: Demografska statistika br. 4-11, Republički zavod za statistiku, Banja Luka. Podaci Ministarstva prosvjete i kulture Republike Srpske, Banja Luka.

Generacije učenika rođene od 1996. do 2003. godine upisivane su u prvi razred osnovne škole u prosječnom omjeru od oko $83 \%$. To ukazuje na činjenicu da je Srpska emigracioni 
prostor iz kojeg odlazi znatan broj reproduktivnog i vitalnog stanovništva, što se najdirektnije odražava na smanjivanje kapaciteta školske populacije. Konstantno smanjenje broja upisanih učenika u prvi razred osnovne škole, sasvim prirodno, odražava se i na smanjivanje brojnog stanja cjelokupne školske populacije.

Opšta stopa nataliteta najdirektnije utiče na brojnost školske populacije u Srpskoj. Baza podataka o rađanju stanovništva Srpske postoji od 1996. godine i na osnovu tih podataka mogu se pratiti njeni učenički kapaciteti. Posljednja generacija koja je upisana u osnovnu školu je generacija rođena 2003. godine.

Predškolsko vaspitanje i obrazovanje obuhvata djecu uzrasta do 6 godina.

Predškolske ustanove postoje u 41 opštini, gdje je prema procjenama oko 6800 ili oko $10 \%$ od ukupne predškolske populacije uključeno u predškolski sistem.

Obuhvat djece predškolskim vaspitanjem i obrazovanjem u narednom petogodištu trebalo bi da se poveća za gotovo dvostruki kapacitet, uz prethodno obezbjeđivanje odgovarajućih prostora i stručnih kadrova.

Tabela 2. Kontigent predškolske populacije

Table 2. Contingent of pre-school population

\begin{tabular}{|c|c|c|c|}
\hline $\begin{array}{c}\text { Godina } \\
\text { (Year) }\end{array}$ & $\begin{array}{c}\text { Broj rođenih } \\
\text { (Number of births) }\end{array}$ & $\begin{array}{c}\text { Muških } \\
\text { (Male) }\end{array}$ & $\begin{array}{c}\text { Ženskih } \\
\text { (Female) }\end{array}$ \\
\hline 2004. & 10628 & 5515 & 5113 \\
\hline 2005. & 10322 & 5302 & 5020 \\
\hline 2006. & 10524 & 5351 & 5137 \\
\hline 2007. & 13110 & 5203 & 4907 \\
\hline 2008. & 10198 & 5262 & 4936 \\
\hline 2009. & 10603 & 5577 & 5026 \\
\hline Ukupno (Total): & 62385 & 32210 & 30175 \\
\hline
\end{tabular}

Izvor: Republički zavod za statistiku Republike Srpske, Demografski bilten br. 4-11.

Smanjenje rađanja u Srpskoj je evidentno od 2000. godine, što se bitnije odražava i na smanjivanje kontigenta školske populacije na svim nivoima. Dosadašnja istaživanja pokazuju da se od ukupnog broja rođenih u određenoj godini upisuje u osnovnu školu oko $85 \%$ te populacije (karakteristike emigracionog prostora). Na osnovu podataka iz Tabele $1 \mathrm{o}$ kontigentu predškolske populacije, evidentno je da će i u narednim godinama doći do opadanja broja osnovnoškolske populacije, u većem stepenu nego što je to bilo izraženo i dosadašnjem periodu.

Ukupno brojno kretanje osnovnoškolske populacije, prema navedenim podacima, pokazuje dva trenda. Prvi je izražena stabilnost u školskim godinama od 1995/1996. do 1999/2000. godine. Već od naredne 2000/2001. godine evidentan je nagli pad broja učenika u osnovnoj školi. Ovdje se radi o generacijama djece koje su rođene u ratu, kao i posljedicama smanjenog nataliteta, te emigraciji vitalnog stanovništva iz Republike Srpske. Uticajem navedenih faktora smanjivan je ukupni kontigent stanovništva Republike Srpske, a time i njene školske populacije (Pašalić, 2007). 
Tabela 3. Brojno kretanje osnovnoškolske populacije u Republici Srpskoj

Table 3. Numerous movements of primary school population in Republic of Srpska

\begin{tabular}{|c|c|c|c|}
\hline Godina(Year) & $\begin{array}{c}\text { Ukupan broj učenika } \\
\text { (Total number of pupils) }\end{array}$ & $\begin{array}{c}\text { Od toga- ženskih } \\
\text { (Therefrom-female) }\end{array}$ & $\begin{array}{c}\text { Od toga-muških } \\
\text { (Therefrom-male) }\end{array}$ \\
\hline $1995 / 1996$ & 125.856 & 61.699 & 64.187 \\
\hline $1996 / 1997$ & 130.153 & 63.569 & 66.584 \\
\hline $1997 / 1998$ & 126.461 & 61.787 & 64.678 \\
\hline $1998 / 1999$ & 125.244 & 61.173 & 64.071 \\
\hline $1999 / 2000$ & 121.197 & 59.017 & 62.180 \\
\hline $2000 / 2001$ & 114.570 & 55.869 & 58.701 \\
\hline $2001 / 2002$ & 114.094 & 55.463 & 58.631 \\
\hline $2002 / 2003$ & 113.366 & 55.169 & 58.198 \\
\hline $2003 / 2004$ & 125.2564 & 60.738 & 64.518 \\
\hline $2004 / 2005$ & 122.862 & 59.513 & 63.349 \\
\hline $2005 / 2006$ & 119.852 & 58.247 & 61.605 \\
\hline $2006 / 2007$ & 116.206 & 56.419 & 59.787 \\
\hline $2007 / 2008$ & 115.430 & 55.975 & 59.455 \\
\hline $2008 / 2009$ & 113.200 & 55.241 & 57.759 \\
\hline $2009 / 2010$ & 108.300 & 52.634 & 55.666 \\
\hline $2010 / 2011$ & 105.200 & & \\
\hline
\end{tabular}

Izvor: Statistika obrazovanja br.2-4, Republički zavod za statistiku, Banja Luka. Podaci Ministarstva prosvjete i kulture Republike Srpske, Banja Luka.

Brojno povećanje školske populacije 2003/2004. godine u odnosu na prethodnu 2002/2003. godinu rezultat je prelaska na devetogodišnje obavezno osnovno obrazovanje, odnosno upisivanja dvije generacije osnovaca u prvi, odnosno drugi razred.

Takođe, primjetno je konstantno smanjivanje ukupnog broja učeničke populacije i nakon uvođenja devetogodišnjeg osnovnog obrazovanja. Za samo šest godina (2003/2004) broj učenika se smanjio za 16.956 učenika (2009/2010). Prosječno godišnje smanjivanje učeničke populacije iznosilo je 2000-2500 učenika do 2008/2009. godine. Znatno osjetniji pad je 2009/2010. godine u odnosu na prethodnu školsku godinu i to za 4.900 učenika. Ovakvo brojno kretanje učeničke populacije direktna je posljedica demografskih kretanja u Srpskoj (negativna stopa prirodnog priraštaja i negativan migracioni saldo). Tako se praktično za četiri do pet godina „gubi”" jedna generacija upisivanih učenika u prvi razred osnovnoškolske populacije.

Istovremeno stanje brojne populacije u srednjim školama je nešto stabilnije, pošto negativni demografski procesi i smanjivanje broja učenika u osnovnoj školi jos nisu značajnije zahvatili generacije koje završavaju osnovnu školu i upisuju se u srednje škole. Taj proces je neminovan za nekoliko godina. 
Tabela 4. Brojno kretanje učenika srednjih škola u Republici Srpskoj

Table 4. Numerous movements of secondary school students in Republic of Srpska

\begin{tabular}{|c|c|c|c|}
\hline $\begin{array}{c}\text { Godina } \\
\text { (Year) }\end{array}$ & $\begin{array}{c}\text { Ukupan broj } \\
\text { učenika } \\
\text { (Total number of } \\
\text { pupils) }\end{array}$ & $\begin{array}{c}\text { Broj učenika u } \\
\text { prvom razredu } \\
\text { (Number of pupils } \\
\text { in the first grade) }\end{array}$ & $\begin{array}{c}\text { Udio u \% učenika } \\
\text { prvog razreda } \\
\text { (Share in percentage of } \\
\text { pupils in the first grade) }\end{array}$ \\
\hline $2000 / 2001$ & 51.283 & 14.891 & 29,04 \\
\hline $2001 / 2002$ & 52.177 & 15.983 & 30,63 \\
\hline $2002 / 2003$ & 50.558 & 15.530 & 30,72 \\
\hline $2003 / 2004$ & 50.128 & 14.938 & 29,80 \\
\hline $2004 / 2005$ & 51.556 & 14.746 & 28,60 \\
\hline $2005 / 2006$ & 49.219 & 14.323 & 29,10 \\
\hline $2006 / 2007$ & 50.703 & 14.250 & 26,07 \\
\hline $2007 / 2008$ & 47.314 & 12.337 & 25,37 \\
\hline $2008 / 2009$ & 46.900 & 11.900 & 27,05 \\
\hline $2009 / 2010$ & 46.200 & 12.500 & \\
\hline $2010 / 2011$ & 47.999 & & \\
\hline
\end{tabular}

Izvor: Statistika obrazovanja (srednje obrazovanje) Republički zavod za statistiku, Banja Luka. Podaci Ministarstva prosvjete i kulture Republike Srpske, Banja Luka

Iz priložene tabele vidljivo je da se ukupan broj srednjoškolske populacije smanjuje sporijim tempom u odnosu na osnovnoškolsku populaciju, sa izuzetkom posljednje dvije godine, gdje je ono osjetnije.

Broj učenika prvog razreda srednjih škola ima udio u ukupnoj srednjoškolskoj populaciji od 25,37 do $30,72 \%$. Njihov broj je u direktnoj zavisnosti od broja učenika koji završavaju osnovnu školu, zatim od toga koliki broj svršenih osnovaca nastavlja obrazovanje u srednjoj školi (srednja škola nije obavezna), kao i od drugih faktora. Dosadašnji podaci pokazuju da skoro cijela populacija učenika koji završavaju osnovnu školu nastavlja obrazovanje u nekoj od srednjih školi.

Najvažniji cilj u ovom radu je da pokažemo da iznijete podatke o osnovnoškolskoj i srednjoškolskoj populaciji treba dobro razumjeti, zatim ih povezati sa drugim parametrima bitnim za ukupno brojno kretanje školske populacije na svim nivoima obrazovanja, te da sve te povezane indikatore treba posmatrati u širem kontekstu, pošto njihov uticaj doseže mnogo dalje od razvoja učeničke populacije, pa čak i obrazovnog sistema u cjelini.

Demografske potencijale u oblasti visokog obrazovanja posmatrali smo tek od 2007. godine, nakon provedenog postupka usklađivanja institucija visokog obrazovanja sa novim Zakonom o visokom obrazovanju Republike Srpske i Okvirnim zakonom o visokom obrazovanju BiH. Nakon izvršenog licenciranja, od 2007/2008. godine u Republici Srpskoj ima:

- dva javna univerziteta

- šest privatnih univerziteta

- dvije javne visoke škole

- sedam privatnih visokih škola

Licenciranjem privatnih visokoškolskih ustanova došlo je do snažne ekspanzije broja studenata na visokoškolskim ustanovama Republike Srpske. Resursi kojima raspolažu visokoškolske ustanove su pretpostavka kvaliteta realizacije naučno-nastavnog procesa. 
Ocjena je da je time došlo do nesrazmjernog povećanja broja studenata u odnosu na cjelokupne demografske resurse kojima raspolaže Srpska. Uz to, primjetan je i pad kvaliteta u visokom obrazovanju, što će u krajnjem imati negativne posljedice za njen društvenoekonomski razvoj.

Tabela 5. Brojno kretanje studentske populacije na visokoškolskim ustanovama u Republici Srpskoj $^{5}$

Table 5. Numerous movements of students population in higher education in Republic of Srpska

\begin{tabular}{|c|c|c|c|}
\hline $\begin{array}{c}\text { Godina } \\
\text { (Year) }\end{array}$ & $\begin{array}{c}\text { Ukupan broj } \\
\text { studenata } \\
\text { (Total number } \\
\text { of students) }\end{array}$ & $\begin{array}{c}\text { Broj studenata na } \\
\text { univerzitetima } \\
\text { (Number of } \\
\text { university students) }\end{array}$ & $\begin{array}{c}\text { Broj studenata na } \\
\text { visokim školama } \\
\text { (Number of students } \\
\text { in higher schools) }\end{array}$ \\
\hline $2007 / 2008$ & 34.441 & 29.125 & 4.882 \\
\hline $2008 / 2009$ & 42.521 & 36.864 & 5.657 \\
\hline $2009 / 2010$ & 44.329 & 38.126 & 6.203 \\
\hline
\end{tabular}

Izvor: Podaci Ministarstva prosvjete i kulture Republike Srpske, Banja Luka Neverifikovani podaci sa visokoškolskih ustanova Republike Srpske

Navedeni podaci pokazuju nagli porast broja studentske populacije u Srpskoj, nakon licenciranja privatnih visokoškolskih ustanova. Paradoksalno je da je broj studenata na visokoškolskim ustanovama gotovo izjednačen sa ukupnim brojem srednjoškolske populacije. Ta nelogičnost proističe iz činjenice da su polaznici novolicenciranih visokoškolskih ustanova postali mnogi koji ne predstavljaju tek svršene srednjoškolce, već je značajan broj onih koji su upisali studije da se doškoluju na jednoj od privatnih visokoškolskih ustanova. Ovu tvrdnju potkrepljuje podatak da privatne visokoškolske ustanove upisuju zanemarljiv broj tek svršenih srednjoškolaca, koji se u dominantnom broju još uvijek opredjeljuju za studije na javnim visokoškolskim ustanovama.

Obrazovni sistem Srpske treba da osigura stvaranje visoko kvalitetnih ljudskih resursa i kreiranje bržeg ekonomskog rasta. U pogledu zahtjeva tržišta rada neophodno je da obrazovni sistem Srpske poboljša kvalitet ponude, jer je nivo obrazovanja kod populacije između 25 i 65 godina starosti ispod nivoa obrazovanja u istoj starosnoj grupi zemalja evropskog područja.

Evidentan je fenomen odliva mozgova (brain drain), što podrazumjeva činjenicu da visoko obrazovana lica napuštaju Srpsku i BiH. Ovi trendovi će se najvjerovatnije nastaviti, jer je u skorijoj prošlosti došlo do redukcije nivoa obrazovanja kod populacije, kao i zbog manjka mogućnosti za zapošljavanje i razvoj.

$\mathrm{Na}$ osnovu toga, može se zaključiti da je trenutna situacija u pogledu obrazovanja i tržišta rada, neorganizovana. Sve reforme koje se dešavaju u sektoru obrazovanja, kao i u sektoru tržišta rada, potpuno su odvojene jedna od druge.

\section{Projekcija razvoja školske populacije}

Projekcije razvoja školske populacije ne pokazuju bitnije promjene u kraćem periodu.

Nedostatak baze podataka ograničava mogućnost izrade projekcija za duži vremenski period.

Ipak, i koncepcija razvoja u naredna dva petogodišta je veoma ozbiljna. Za njihovo projektovanje bile su potrebne široke konsultacije sa stručnjacima različitih profila. 
Naša dosadašnja istraživanja u demografskom razvoju školske populacije Republike Srpske pokazala su se izuzetno pouzadnim.

Projekcija razvoja demografskih kontigenata mlade populacije Srpske zasnivaju se na dosadašnjim demografskim kretanjima: nizak natalitet, negativna stopa prirodnog priraštaja, negativan migracioni saldo, posebno za vitalnu kategoriju stanovništva, neravnomjeran razmještaj stanovništva, sve izraženiji proces urbanizacije....

Tabela 6 - Projekcije razvoja demografskih kontigenata mlade-školske populacije Table 6 - Development of demographic projections of young school population contingents

\begin{tabular}{|c|c|c|}
\hline $\begin{array}{c}\text { Demografski kontigenti mlade populacije } \\
\text { (Demographic contingents of young } \\
\text { population) }\end{array}$ & $\begin{array}{c}\text { Projekcija } \\
\text { (Projection) } \\
2015 .\end{array}$ & $\begin{array}{c}\text { Projekcija } \\
\text { (Projection) } \\
2020 .\end{array}$ \\
\hline $\begin{array}{c}\text { Predškolska populacija (0-6) } \\
\text { (Pre-school population) }\end{array}$ & 50.000 & 45.000 \\
\hline $\begin{array}{c}\text { Osnovnoškolaska populacija } \\
\text { (Primary grammar school population) }\end{array}$ & 93.000 & 84.000 \\
\hline $\begin{array}{c}\text { Srednjoškolska populacija } \\
\text { (Secondary grammar school population) }\end{array}$ & 39.000 & 35.000 \\
\hline $\begin{array}{c}\text { Visokoškolska populacija } \\
\text { (Higher school population) }\end{array}$ & 30.000 & 25.000 \\
\hline
\end{tabular}

Izvor: Republički zavod za statistiku, Demografski bilten 4-11 Banja Luka

Projekcije razvoja demografskih kontigenata mlade populacije Srpske predstavljene su u dva naredna petogodišta. Predškolska populacija će smanjivati svoje demografske kapacitete usljed konstantnog smanjivanja stope nataliteta, a prema proračunima za narednih desetak godina smanjenje tih kapaciteta iznosiće za oko jednu četvrtinu od sadašnjih kapaciteta.

Osnovnoškolska populacija će u narednom petogodištu biti smanjena za oko 15000 učenika, a u narednih deset godina za više od 20 000, što će usloviti krupnije promjene u organizaciji i funkcionisanju ovog obrazovnog nivoa u Srpskoj.

Srednjoškolska populacija će, u direktnoj zavisnosti od demografskih kapaciteta osnovnoškolske populacije, bilježiti značajniji brojčani pad populacije i smanjiti brojno stanje do 2020. godine na oko 35000 učenika.

Promjene u demografskim kontigentima mlade populacije Srpske su poseban izazov za visoko obrazovanje. U prvom redu, neminovna je harmonizacija visokoškolskih ustanova sa demografskim ekonomskim, socijalnim, kulturnim i obrazovnim realnostima (Pašalić, 2004).

Projekcija razvoja studentske populacije temelji se na više faktora, prije svega demografskom, razvojnom, tehnološkom, i drugim. Pouzdano je da broj studenata neće imati dalji rast, već opadanje ukupnog broja. Očekivano brojno smanjivanje srednjoškolske populacije će najdirektnije uticati na smanjivanje brojnog stanja visokoškolske populacije. Uz to, „doobrazovanje" generacija iz kontigenta aktivnog stanovništva će opadati. Procjenjuje se da će u narednom petogodištu broj studenata na prvom ciklusu studija u Srpskoj iznositi oko 30 000, odnosno za pet hiljada manje na kraju drugog petogodišta, 2020. godine.

Ako se analiziraju sadašnji kapaciteti visokoškolskih ustanova, neminovno je da će se sa smanjivanjem ukupnih studentskih kapaciteta smanjivati i postojeći broj visokoškolskih ustanova, prije svega iz razloga nemogućnosti obezbjeđivanja kritične mase studentske populacije, ali i iz drugih razloga. Pozicioniraće se one visokoškolske ustanove koje se izbore za kvalitet, odnosno osiguranje visoko kvalitetnih ljudskih resursa. Dugoročni razvoj Srpske ovisiće isključivo o kvalitetu njenih ljudskih resursa, što će pozicioniranije visokoškolske ustanove prepoznati, shvatajući da su promjene moguće samo ako se odaberu 
najkvalitetniji ljudski resursi, te da im se mora pružiti podrška i dodatno znanje koje je za to potrebno.

\section{Zaključak}

Razvoj školske populacije u Republici Srpskoj predstavlja najvažniji dio njenog obrazovnog sistema.

Četiri godine rata ostavile su ozbiljne društveno-ekonomske i demografske posljedice, koje će se manifestovati i u narednim decenijama društveno-ekonomskog i demografskog razvoja Srpske.

Prostor Republike Srpske je niskonatalitetno područje, stopa fertiliteta je veoma niska, što je posljedica planiranja porodice, postratnih trauma, raseljavanja stanovništva i teške socijalno-ekonomske situacije. Smanjivanje rađanja ima za posljedicu smanjivanje broja školske populacije.

Ukupno brojno kretanje osnovnoškolske populacije pokazuje dva trenda: prvi, stabilnost do 2000. godine, drugi, nagli brojčani pad od 2001. godine, što je posljedica demografskih kretanja u Srpskoj.

Trenutno stabilnije brojno kretanje srednjoškolske populacije je kratkoročnog karaktera, čije će osjetnije smanjivanje ukupnih kapaciteta uslijediti za nekoliko godina. Demografski potencijali populacije u visokom obrazovanju imaće kao posljedicu opadanja demografskih potencijala u osnovnom i srednjem obrazovanju trend smanjivanja.

Demografski potencijali školske populacije Srpske uticaće na njen društveno-ekonomski razvoj, kroz porast zaposlenih, interakciju tržišta rada i nivoa obrazovanja, što će omogućiti njen koherentan i jedinstven pristup cjelokupnom društveno-ekonomskom razvoju.

\section{Literatura}

Pašalić S, Marijanac M, Đurđev B, Marinković D. Demografski razvoj i populaciona politika Republike Srpske. Bijeljina: IP Mladost. 2006;1-220.

Europian Commission, Key data on education in Europe, Brussels, 2000.

Pašalić S. Plan institucionalnog razvoja Univerziteta u Istočnom Sarajevu 2003-2008. godinemeđunarodni projekat, Univerzitet u Istočnom Sarajevu, Istočno Sarajevo. 2003;1-125.

Pašalić S. Stanovništvo Semberije. Istočno Sarajevo: Zavod za udžbenike i nastavna Sredstva. 2004;1232.

Pašalić S. Reforma obrazovanja u BiH sa posebnim osvrtom na visoko obrazovanje, Zbornik radovaUniverzitetska nastava, Pedagoški fakultet, Bijeljina. 2003;1:15-23.

Pašalić S. Novi obrazovni profili nastavnika za reformisanu osnovnu školu, Nova škola, Pedagoški fakultet, Bijeljina. 2005;2:10-17.

Pašalić S., Dragosavljević P. Demografski razvoj školske populacije i optimalizacija mreže škola u Republici Srpskoj, Banja Luka: Ministarstvo porodice, omladine i sporta. 2007;1-87.

Statistika obrazovanja- osnovno obrazovanje, Bilten br.9, Republički zavod za statistiku, Banja Luka. Statistika obrazovanja- srednje obrazovanje, Bilten br.8, Republički zavod za statistiku, Banja Luka.

Statistika obrazovanja- visoko obrazovanje, Bilten br.6, Republički zavod za statistiku, Banja Luka. 


\title{
PROJEKCIJE RAZVOJA MLADE (ŠKOLSKE) POPULACIJE REPUBLIKE SRPSKE IZ DEMOGRAFSKE PERSPEKTIVE
}

\author{
Stevo Pašalić, Mitar Novaković, Momčilo Pelemiš
}

\begin{abstract}
The significance of this scientific work is in its perspective on the exiting state and the fact that it gives us vision of the development of demographic potentials of school population in interaction with socioeconomic development of the Republic of Srpska.

General hypothesis (which ensues from the aim of researching) is to classify the researched phenomenon into one of the crucial components of the overall development of the Republic of Srpska and that it is the consequence of demography that demands a new approach in the projection of development of that phenomenon.

The expected results of this research have a special value for the social community, such as the development of school population at all levels and interdependence with socio-economic development of the Republic of Srpska.

While researching the balances of school population at all levels the development of the phenomenon is monitored, and studies need to provide specific recommendations on the adjustments of educational profiles at the institutions of higher education, to the demands of labour market in the Republic of Srpska.
\end{abstract}

Key words: population, contingents, educated profiles, human resource. 